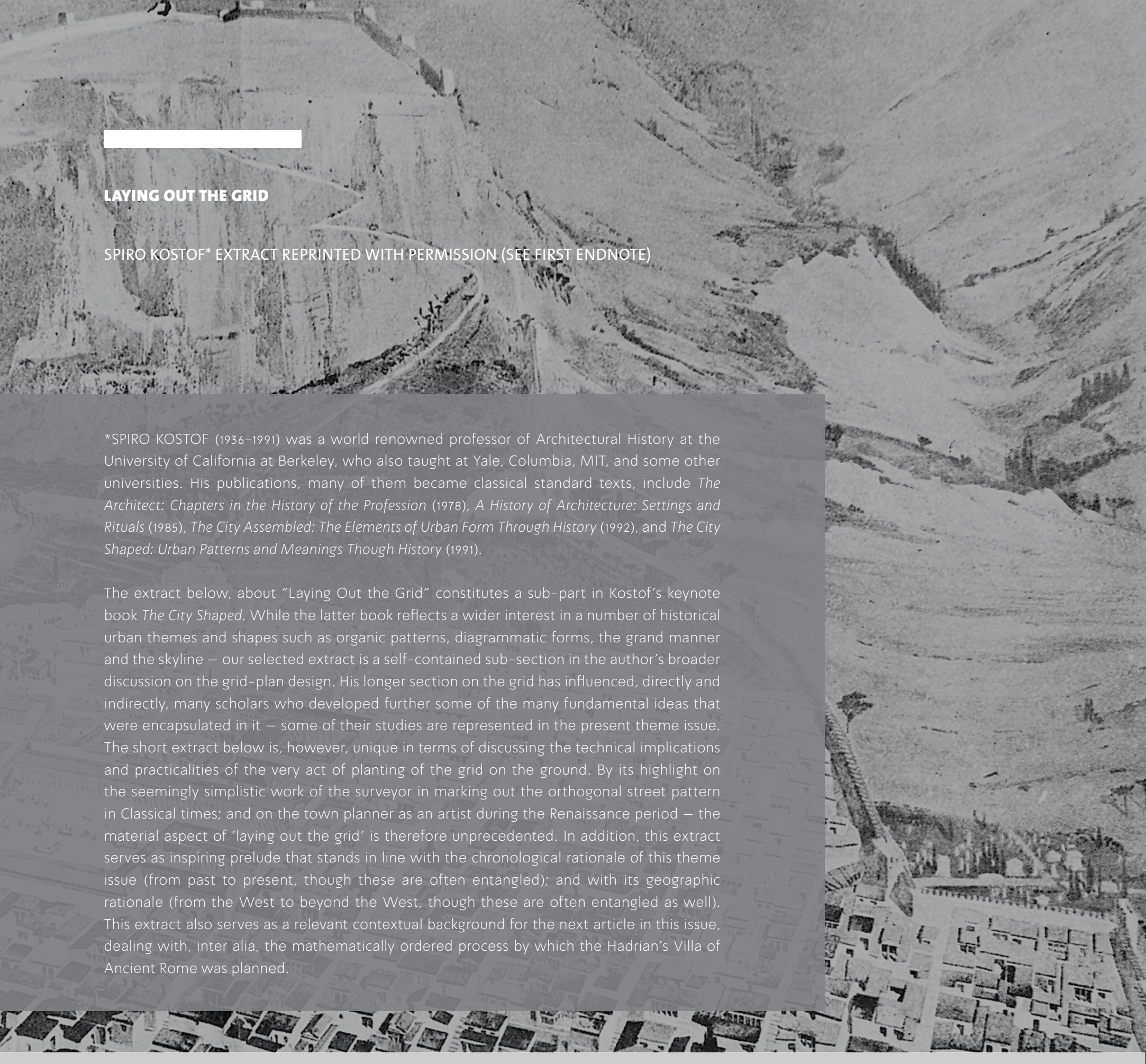

This article is a reprint of a piece written by Spiro Kostof (1936-1991), a renowned professor of Architectural History at the University of California at Berkeley. The piece originally constituted a sub-section in a broader discussion of gridded configurations worldwide (inside Kostof's: The City Shaped, reprinted with permission, for more details see article's first reference). The piece has influenced many scholars who developed further some of the many fundamental ideas regarding the urban grid as were inspiringly raised by Kostof. However, our selected sub section on the gid is "lassical" in terms of discussing the

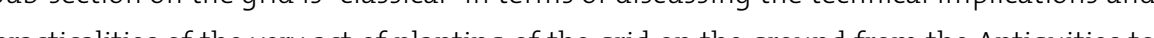
the Renaissance. Through a highlight on the seemingly simplistic work of the surveyor in marking out the orthogonal street pattern; and on the town planner as an artist-this extract is unique in reviling, before discussing any theoretical dimension, the material aspects behind the "laying out the grid" in Classical periods.

The word "grid" as it has been used here is a convenient, and imprecise, substitute for "orthogonal planning." "Gridiron," in the United States at least, implies a pattern of long narrow blocks, and "checkerboard" a pattern of square blocks. These are the two commonest divisions of a grid plan. The basis of a true checkerboard is bound to be modular, since the quadratic units produced by the coordinates are equal. A gridiron may prove to be modular or not, depending on the regularity of the long narrow blocks and the relation of their size or not, depending on the regularity of the
to the public buildings and open spaces.

True checkerboards are rare. One thinks, in chronological order, of the unfinished Urartian town of Zernaki Tepe in eastern Turkey (eighth century BC); early Roman colonies in northern Italy such as Verona; Kyoto; a smattering of medieval planted towns like Lalinde (Périgord, France); the towns of New Spain; the initial schemes of American towns like Omaha, Nebraska; and Cerdà's Barcelona Rectangular blocks are much commoner But as a rule a grid plan will

But the street grid and block pattern, the object of primary concern for historians of urban planning, do not in themselves explain the character of the city-form. At the time that this
over-all grid is laid out, a second, more detailed grid is put in place - that of plot parcels over-all grid is laid out, a second, more detailed grid is put in place - that of plot parcels within the block. Decisions affecting allocation of land to owners or renters need to be made

12 Architext / Vol. 7, 2019, pp. 12-25 
grid is likely to endure longer than this closer-grained, and less visible, division, it is because streets, as public space, are under official scrutiny while private parcels can stage their own internal transformations. Nonetheless, street grid and plot grid will always interlock and be interdependent.

Two other important considerations affect the quality of gridded urban form. The shape of The land is one of them : the technology of surveying and its relative sophistication at a given time and place is the other.

\section{On the site}

As always, one begins with the land. Where the land is flat, the grid is on its own. This is the closest the city planner will come to a blank sheet of paper. On level ground a standardized format can be painlessly repeated. The planning agency may indeed decide to create a level site, filling in depressions and shaving off wells. Roman towns in Gaul, it has been observed, "demonstrate a quite remarkable disdain for existing features, either natural or manmade. The demand was for a virtual tabula rasa... [so that] the new city could be shown in a condition of 'perfect horizontality'." (Drinkwater, 1985, 53)

Even on flat land, gridded settlement patterns may reflect the broad physical facts of the site River towns, for example, will tend to run their main streets parallel to the waterfront,

Figure 1

Priene (Turkey), reconstruction of the town in the mid-forth century $B C$ an application of gridiron planning to a topographically improbable site (source: German excavations of 1895-8, Wikimedia Commons, https: commons.Wikimedia.org/Wiki/ Fille:Panorama_of_Priene,_according

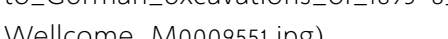

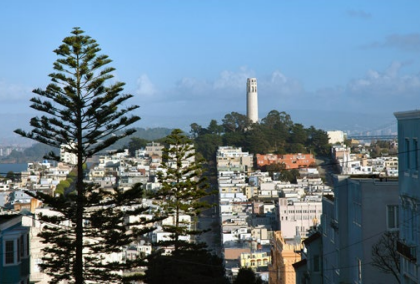

Figure 2

The Grid of San Francisco, California, marches with equal measure across infilled bay land and up the steep side of Telegraph Hill (source: Stephen Sommerhalter. Wikimedia Commons, https.//licommons.

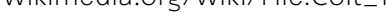
Russian_Hill.jpg)

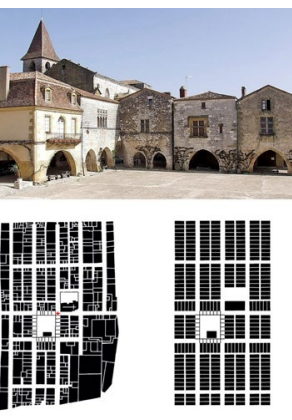

Figure 3 prcel and gridded pons of Monpazter, the thirteenth-century bastide town in Aquitaine in southwest France. Founded and built by King Edward I of England, who was also Duke of Gascony this commune today is a member of the "Les Plus Beaux Villages de France" ("The most beautiful villages of France") association (source: Klaus Schäfer, Wikimedia Commons, https://commons.wikimedia.org/wik/ File:Beispiel_Monpazier.jpg) with a small number of connecting cross-streets. The bastide of Castelsarrasin on the Garonne in southwestern France is a case in point. Later, the river ports of colonial France in North America, grids of long and narrow shape, exemplified more formal castings of this sympathetic street alignment.

The incidence of a pure, uncompromised grid over rolling topography is rare. The most celebrated instance from antiquity is Priene's well thought-out grid from the fourth century . ground at the southern end of a spur sloping south, east and west. The city blocks were terraced like the seats of a theatre along the main east-west streets, and the north-south streets for pedestrians were cut into steps in places. At medieval Lübeck, the disregard for natural topography can be rationally explained. The city was surrounded by the River Trave, the city core was along a ridge at the high point of the site, and straight streets down the slope were the shortest distance between center and the river piers. Modern instances like San Francisco are speculators' shortcuts; the challenge of coping with lots of slopes is passed on to the buyers. [Fig 2]

The common rule about street grids is to seek a compromise between natural irregularities and the abstract rigor of the right angle. We need look no further than medieval new towns to find a wealth of intuitive and expedient adjustments of reticulate city-form to the facts of local terrain. Among hundreds of bastides, uncompromised grids like Monpazier and AiguesMortes in France and Flint in Wales are extremely rare. [Fig 3] They occupy level ground, and are usually framed by the rectangle of city walls. The majority of new towns never were fortified, and not being so delimited at the start, their overall appearance was frayed at the edges. They sat on uneven terrain, sometimes next to an extant castle settlement which had chosen its rough perch advisedly. For the most part, therefore, the layout was the product of "a primarily local pempircal appoach in which a geneal familiaity with the bastide form was

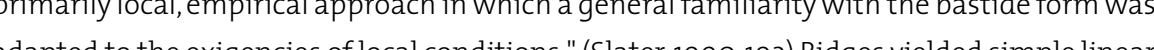
grids of one main street and a parallel set along the slopes (e.g., Villefranche-du-Oueyran, St.-Pastour). On rounded hilltops, the annular plan which would have resulted from "organic" growth was simply squared (e.g., Donzac). The planners of New Winchelsea gridded as much of the hilltop as they could, and left the irregular edges for odd-shaped house lots and grazing ground. Beaumont acknowledged the shape of its hill-back by bending the grid blocks north 
of the marketplace so that they are a few degrees out of line with those to the south. Prior settlements and major roads affected the new town to the extent that it was expeditious and economical to conserve street surface. The two bastides of Villeneuve-sur-Lot, built on opposite banks of the river ten years apart, demonstrate this dependence: the older town on the right bank, built on virgin ground, is quite regular; its companion on the left bank, where a village and two strongholds of the lord of Pujols already existed, has a much looser form with large angular blocks.

As regards the general orthogonality of these hundreds of plans, it is well to remember that this was the only option for rational urban design open to the Middle Ages. It was the only system that facilitated the calculation of area and the coordination of parts. Until the Renaissance, planners did not have the instruments to construct mathematically accurate maps of geographic or urban forms. "In the Middle Ages," David Friedman writes, "it is only on an orthogonally articulated plane that the precise location of a point could be known." ( $(988,51)$ Siena's planned organicism, for instance, was achieved within an extant scheme. Out in the open, this was a different story.II was only during the Renaissance that the possibility opened up to survey and record geographic features and irregular city shapes.

\section{Surveyors and theorists}

The simplicity of marking out an orthogonal street pattern made the grid a feasible cityform even for technologically unsophisticated cultures. The training of those who did the actual division on the site could be fairly basic. The tools remained in use for long spans of time, with periodic improvements that made their performance more accurate. Ropes and pegs marked straight lines at all stages of history. Alberti's hodometer or "road-measurer" was described in Vitruvius fifteen hundred years earlier: an ordinary cart wheel of known circumference, the revolutions of which are recorded automatically

Egyptians could determine the horizontal and the difference in height between two points. They had a simple sighting instrument, and used a primitive form of the transit,called groma, which was passed on to the Greeks and Romans and remained the standard land-surveyor's instrument until improved versions were developed in the Renaissance. [Fig 4] In this transit, one of the lineals was used for sighting a main direction, and the other to determine the direction in the field at right angles to it.
In Greek colonial enterprises, the horistes was a key member of the original expedition; the word literally means the establisher of boundaries (horoi). He was a man of practical skills. The division was done in long narrow strips.' Diodorus in the late first century BC describes the founding of a colony: first, the ritual consultation of an oracle (the religious component); then, the location of a spring (water supply); the building of a city wall (defense); the laying out of a grid of broad avenues or plateiai (for Thurii which he is describing, there were four in one direction and three others at right angles to them): and after this primary order the subdivision into nirow blocks for houses, served by lesser strets called stenopi, basially footpaths between lots The houses fronted on stenopoi, public buildings on plateiai. The blocks were 100 by 300 feet $(30 \mathrm{X} 90 \mathrm{~m})$. A portion of the city was strictly reserved for civic and commercial buildings; some economic activity was also incorporated in the residential zones. As for public buildings, the temples sometimes fitted the grid and sometimes were oriented independently (e.g., Agrigento, Paestum), presumably for religious reasons. The theatre often took advantage of a natural slope for the arrangement of seats.

The case of Hippodamus of Miletus is puzzling. We have no working details for the system attributed to him, but what distinguished it, it seems fairly certain, was the fact that it relied on a theortical formula of geometry more so than the puely techncal (and enpril) on a theoretica fo practice or hand suveys and the site.If we can Jus dectors, each with its own rectilinear street pattern; the setting aside of public areas, delimited by boundary markers, for specific public functions; and provision for a placement of public buildings. From the example of Rhodes, to the extent that its ancient street pattern can be reconstructed, we might deduce that the Hippodamian geometric system had a triple order of division. The largest element was a square of which the sides measured one stadion each (a variable unit of about 600 feet or $180 \mathrm{~m}$.). Each of these squares was quartered to produce squares one-half stadion to a side: and each of these was in turn divided into six parts to form rectangles measuring 100 by 150 feet (30 by $45 \mathrm{~m}$ ) Whether the system became stablished

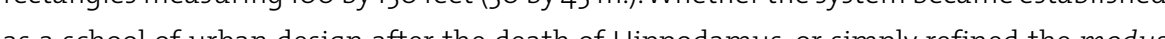
as a school of urban design af operandi of the common surveyor, is impossible to say

We know a lot about the training of Roman surveyors. It involved knowledge of arithmetic, geometry, and law. On the whole they worked with squares and rectangles, and applied triangles, which they used not for surveying by triangulation but for things like finding the 
width of a river without crossing it and possibly for calculating height. Other instruments of the trade were the set-square, of most use to building surveyors, the water-table to establish precise horizontality, the portable sundial which helped with orientation, and of course measuring-rods and chains.

There was no strict separation between planned cities and the rectangular land survey of the agricultural land around them, nor between surveyors of rural land and military or urban,

Until the Renaissance, rectilinear layouts were generated by simple rotes of surface geometry. The surveyors knew how to create a perpendicular to a given line on the ground, and to establish the two coordinates to which parallel survey lines could be drawn. In many bastides, the Pythagorean triangle with sides of 3-4-5, which permitted the tracing of right angles with the help of a cord of 12 knots, was widely used. More complicated patterns based on constructive geometry, quite familiar in the design of Gothic cathedrals, could be transferred to the field but were not. In other words, the laying out of cities was not looked upon as an elevated problem of architectural design.

One case that does submit to analysis is Grenade-sur-Garonne, founded about 1300 by the seneschal of the king of France in the county of Toulouse. The plan is a late version of the town type developed by the planners of Alphonse de Poitiers around 1255, example of which are Ste.-Foy-la-Grande on the Dordogne, Montréal-de-Gers, and Edward I's Monpazier. In this type the central feature is the intersection of two pairs of streets parallel to one another and at the same distance apart. The square they enclose is the market. Typically the blocks of these central strips are square, whereas the rest of the plan uses rectangular blocks. The geometric basis of the Grenade plan is evident in the position of the general survey lines by which the town was laid out It is the system of rotation described in the early thirteenth century "Sketchbook" of Villa d de Hon sy This is how tworks The distance bew This is how it works The dstance bew define the central he of square blocks, is 210 feet $(64 \mathrm{~m}$.). This was a primary decision of the town plotter. Then he took the diagonal of a square 210 feet on the side, which is 297 feet ( $90.5 \mathrm{~m}$.), and used it to establish the distance between the main axes and the first secondary axes. This process, repeated, gave the sizes of the blocks in the outer section of town (Boucher, 1972, 43; Friedman, 1988, 132-33

\section{The Town planner as artist}

Is there any evidence, for the period before the Renaissance, of Gothic masters with knowledge of advanced theoretical geometry, masters associated with cathedral workshops, taking up the town grid as an artistic problem? David Friedman had argued just such a case in his book on the Florentine new towns of the fourteenth century (Friedman, 1988).

These towns - San Giovanni, Terranuova, Castelfranco, Pietrasanta and Scarperia in the upper Arno Valley and Firenzula in the Apennine region - were located in the countryside noth Armo vally -S and east of he mother a to all of them. The dominant long axis was usually a section of the major road on which the town was located; an extended piazza was laid at right angles to this. A defensive wall gave the settlement finite dimensions from the beginning. A road within the walls, intended for the movement of troops along the defensive perimeter, was second only to the main street in width. Finally, there were four equivalent neighborhoods at the corners, each with its own internal cross-axis.

It is Friedman's opinion that this scheme, in contrast to the constructive geometry familiar to Gothic design, represents a sophisticated use of sine geometry specifically trigonometry. to Cothicdesign an sine functiss are and chords. That sine geometry may have been the basis of the llorentine plans is suggested, among other things, by the fact that block depths diminish from the center out, the deepest facing onto the main street, followed by three progressively shallower blocks all retaining the same width. It is not likely that this gradation represented a social hierarchy. Magnates were specifically excluded from the new towns. So the progression is largely an abstract one of geometry.

If sine geometry was indeed used here, it would constitute a unique case in medieval urban design Sincegeme try of a a lvanced theoretical aplication had traditionaly beenassociated design Sing the Midde Ages with astronod in the Mid a a was wh astrono dimensions. It was manifested in two things. One was in mariners' charts that provided practical navigational information based on direct observation of the earth's surface with the aid of scientific instruments. These portolan charts, as they were called, have a characteristic pattern of radiating lines forming a web over their surface-a pattern associated with the rose of the winds, which in turn was part of the fully developed magnetic compass - and many 


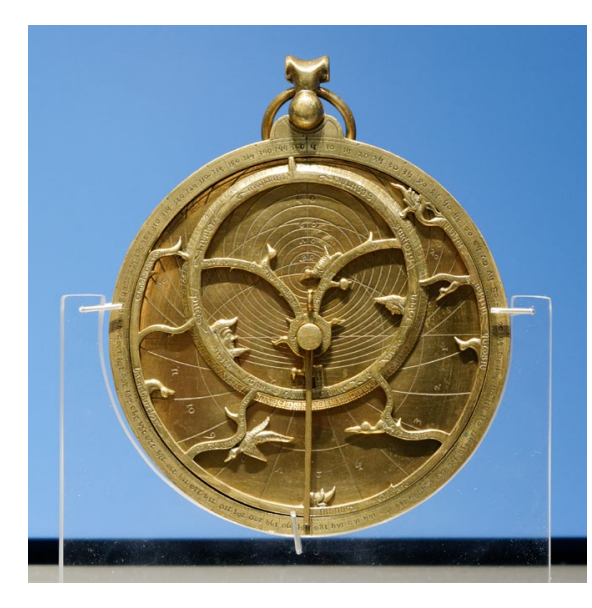

Figure 5

An Islamic astrolabe (source: Marie-Lan Nguyen, Wikimedia Commons.

https://en.wikipedia.org/wiki/A_Treatise_ on_the_Astrolabe\#/media/File:Chaucer_ Astrolabe_BM_1909.6-17.1.jpg)
Sets of parallellines which yield a proportional system comparable to that of the Florentine new town grids. The other application of sine geometry was in planispheric astrolabes, with their sighting rule (the length of the disc's diameter and pivoted at its center) used for taking observations. [Fig 5] A simpler instrument derived from the astrolabe was the quadrant, and both astrolabe and quadrant were known in Europe as early as the eleventh century.

The Florentine plans use the sine pattern of portolan charts and astrolabes, and chord tables Plando Fibonacci's Pratica Ceometriae (Practical Ceometries), written in Pisa The quadrants. Trathal tools of surveying - the line or rod and the simple instruments for measuring right angles - would do the job. The surveyor need only lay down a baseline, the axis of the town's main street, and then strike a line perpendicular to this axis. Then, measuring out the chords of 11, 22, 33, 44, and 55 units of arc adjusted to an appropriately sized circle, he would fix the limits of the five units on either side of the town. Survey lines set out from these points on the perpendicular axis parallel with the base line would complete the skeleton of the plan. But the main decisions came prior to this and they were the critical ones. Someone had to calculate the size of the circle: someone projected the chords of arcs 22,44 , and $5566^{\text {th }}$ of the circurference to Friedman argues, was a Designer. [Fig 6 ]

This conscious artistic creation of Florentine designers that reached beyond practical tasks of surveying and parceling presaged the Renaissance attitude that a city, like a major building, should be the product of architectural design In the next century Alberti and others would equate a city with a palace. "The principal ornament of a city," in Alberti's words, "is the orderly arrangement of streets, squares, and buildings according to their dignity and their function." Beginning with Filarete's ideal city vision of Sforzinda [named after Francesco Sforza, then Duke of Milan]. Renaissance architects projected ideal cities with fixed perimeters and fully urban design is clear

One of the earliest instances is in Fra Giocondo's 1511 edition of Vitruvius, where a woodcut illustrates Vitruvius's famous passage about orienting a city's streets in such a way that none of them would face the major points of the compass, from where the strongest unhealthy winds were thought to blow (Hamberg, 1965). The woodcut shows an orthogonal street
Figure 6

The gometry of the receding block depths Florentine new tomn founded il tasy, a be reconstructed as the product of the radius of a circle, inscribed in the foursquare centre of the plan. as it is rotated in successive 150 increments. Although. this description can account for the plan it is probably not the method that was used by the city's surveyors. A more likely explanation is that Terranuova's designers took the dimensions of the town plan from numerical entries in trigonometric tables derived from measurement of the chords of Kostof's.
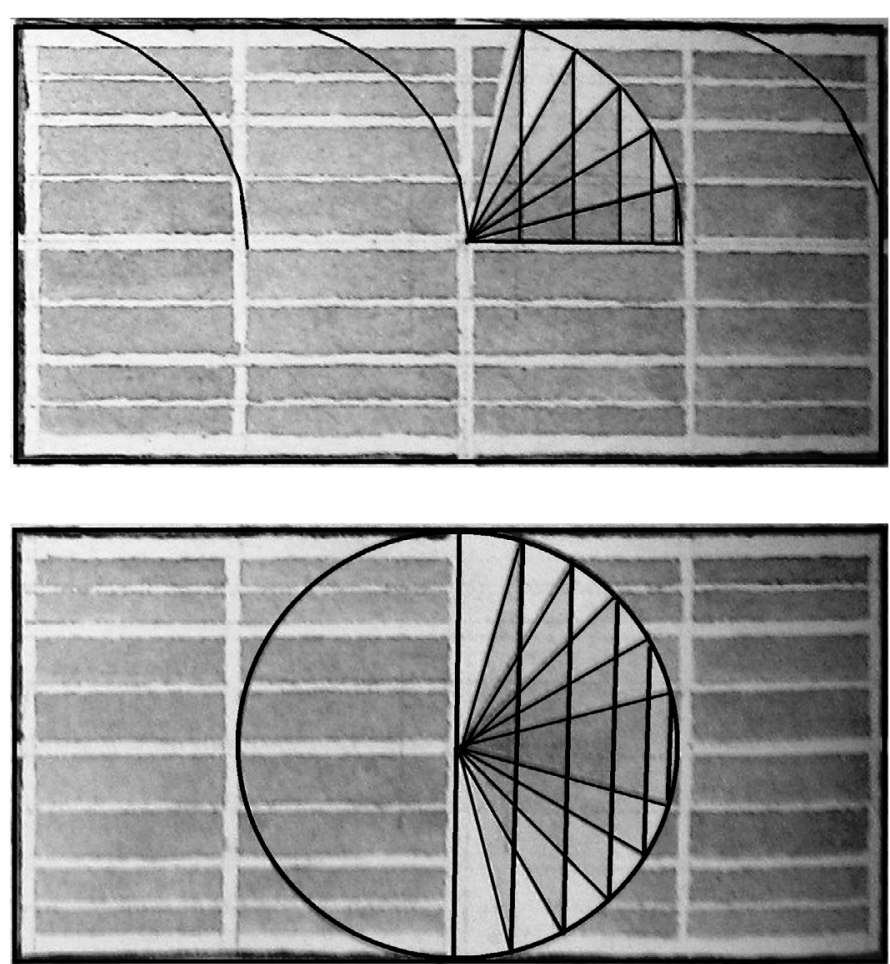

each of its sides representing one of the winds and none of them running parallel with any of the streets. What is novel in Fra Giocondo's drawing, however, is that this geometric figure of the wind rose is coordinated with the streets, the size of the blocks, and the size of the town. Here we have an original Renaissance contribution for which there is no basis in the Vitruvius passage. Something like this coordination of circle-based geometry with a grid was that

In making this drawing, it is likely that Fra Giocondo had in mind the ancient plan of Naples, the Greek Neapolis (Hamberg, 1965). Like that, his street system shows three horizontal streets wider than the vertical ones. ${ }^{2}$ As rebuilt at the end of the fifth century $B C$, modern field work has shown, Naples had three long streets a stadion (in this case about 607 feet or $185 \mathrm{~m}$.) apart from one another, and 20 cross-lanes at regular 121.5 foot $(37 \mathrm{~m}$.) intervals. So the house- 
Figure 7

Pan of Imola (Italy) by Leonardo ichnographic plan of the Renaissan is set within a large circle divided into eight wedge-shaped sectors. The circle's spokes are labeled with the names of the eight winds. These clues reveal the secrets of how the plan was produced. An early surveyor's transit developed by Leonardo consisted of a circular disc divided into eight parts, with a compass at its center. The transit was set up to align magnetic north with the north wind, thus assuring a constant reference for observations taken from various points (source: Saliko, Wikimedia Commons, hiles.t/commons.wikmedia.orghwik/ of_Imola.jpg)

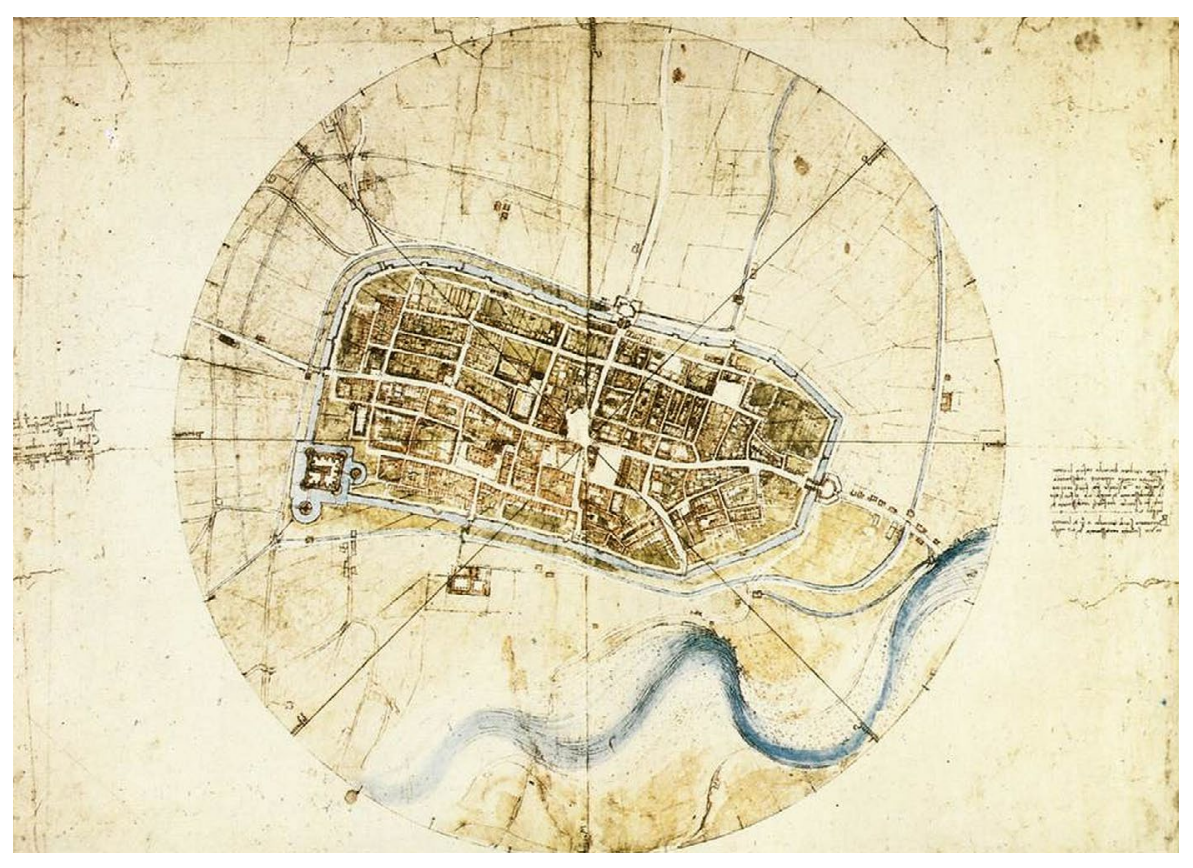

blocks had a proportion of 5:1. The lines of this scheme still survive in central Naples. The long streets slope gently toward the east, which is the only wind direction considered healthy by Vitruvius and his sources. The cross-lanes are steeper, facing south to the harbor. But in both directions the streets are 22.5 degrees from the meridian or the longitudinal compass line, which is what Vitruvius's prescriptions suggest as the proper way to site a city's streets.

In another drawing attributed to Fra Giocondo an ideal version of the original Naples plan seems to be shown, with a circle or wind rose in the middle divided into 16 points. Two of the points correspond to the midllemostlongtidinal line of the steet pattemn and two to one of the transverse patron in Naples, had an active patron in Naples, had an active interest in Classical antiquiny, and some attempts were in fact made during his reign to revive the Greek plan of Naples by extending the long streets and opening up and clearing all the lanes. The drawing is probably related to that process of resurrection.
These urban diagrams of Fra Giocondo, besides confirming the new bond between street grids and circles, are important for another reason. They belong in the development during the Renaissance of a new way of representing cities graphically - namely, as an ichnographic or ground plan, the sort of thing we take for granted as a city map today. The more common renditions of cities, in oblique projection or in bird's-eye view, were related to the invention of Renaissance one-point perspective, which gave artists the ability to represent threedimensional space on a flat surface The ichnographic plan, on the other hand, shows the city from an infinte num refviewpoints all perpendicula to ach topographical feature. Unconcerned $w$ Unconcernedwing actual appearance, this highly complicated abstraption re to a two-dimensionalirecodo solds and voids. And hisground plan, known to the Romans but abandoned in the Middle Ages, became possible again only with the development of the advanced surveying techniques and instruments during the course of the sixteenth century.3 [Fig 7]

What is important to stress is that the new scientifically surveyed plan, and the contemporaneous development of mobile artillery, led to reviewing cities as ideal diagrams. Cities began to be studied with detachment as patterns into which all elements can be entered to form a perfect scheme New treatises disseming per the grid Most in rention of the grid. Most 
City Shaped by Spiro Kostof. @ 1991 Thames and Hudson Ltd, London, pp. 124-132. Text . the guest editor in general line with Kostof's.

1. The term used for this division, per strigas, was actually coined by a modern scholar Castagnoli (1971). Striga in Latin means" a long line of grass or corn cut down, a swath," by extension a"plough furrow." In Roman parlance the system of strigae and scamnae referred to an old method of land division adopted especially in public arable land in the provinces, where strips were arranged lengthwise (strigae) and breadthwise (scamnae) in relation to the surveyor's orientation. See Dilke $(1961,424)$.

2. The very nomenclature of platea and angiportus (Latin for stenopos), first used by Vitruvius (vol. , vi, 1) and also in a passage of Caesar's De bello civili (vol.1, 27), must refer to the Greek grid, and not the Roman where there is no such distinction of street widths. So even though the blocks in Fra Giocondo's woodcut are square, i.e., Roman rather than Greek, the differentiation of street widths and the use of the words platea and angiportus imply that he was thinking of a Greek system.

3. The surveyor's transit, for one thing, was now able to fix a topographical feature relative to two or more points by simple triangulation. Alberti's transit had a circular dial divided into 48 degrees. parts corresponding to the eight winds, each further subdivided into eight degrees. At the center of this disk was a magnetic compass" (Pinto 1976, 40) At the beginning of the survey masnetic north was lined up with the north wind (tramontana). The megnetic meridian thus provided a constant eference for observations taken from a number of different points. Also pivoted at the centerwas a movable sight vane. Alberti had described a process similar to that used by Leonardo at I mola in his Descriptio urbis Romae, dating from ca. 1450. Johannes Praetorius's much touted "invention" of the modern surveyor's transit about 1600 was probably nothing more than the standardization of instruments already in use throughout the sixteenth century.

4. Scamozzi was among the first to reverse the customary graphic differentiation between blocks and streets by shading the streets and squares rather than the blocks.

\section{Bibliography:}

Boucher. F. "Medieval Design Methods, 800-1560," Gesta 11, 2 (1972). pp. 37-5.

Castagnoli, F., Orthogonal Town Planning in Antiquity (Cambridge, Mass: MIT Press, 1971).

Cataneo, P., I Quattro primi libri di architettura (Venezia: Libro Primo, 1554).

Caesar, J., Commentarii de bello civili, III vols. (in Latine, 1 BC)

Dilke, O. A. W., "Ground Survey and Measurement in Roman Towns," in F. Grew and B. Hobley (eds). Roman Urban Topography in Britain and the Western Empire, CBA research report no. 59 (London, 1985), pp. 6-13.

Dilke, O. A. W., "Maps in the Treatises of Roman Land Surveyors", Geographical Journal 127, 4 (1961), pp. 417-426.

Drinkwater, J. F., "Urbanisation in the Three Gauls: Some Observations", in F. Grew and B. Hobley (eds), Roman Urban Topography in Britain and the Western Empire, CBA research report

Friedman, D., Florentine New Towns: Urban Design in the Late Middle-Ages (Cambridge, MA MIT Press, (1988).

Hamberg. P. G. "Vitruvius, Fra Giocondo and the City Plan of Naples," Acta archaeologica 36 (1965), pp. 105-125.

Pinto. J. A... "Origins and Development of the Ichnographic City Plan," Journal of the Society of Architectural Historians, 31 (1976), pp. 35-50.

Scamozzi, V., Lidea della architettura universale (Venetia: Giorgio Valentino, 1615).

Slater, T. R. (ed.), The Built Form of Western Cities (Leicester: Leicester University Press, 1990).

Vitruvius, The Ten Books on Architecture. Translated by Morris Hicky Morgan (Cambridge (MA) Harvard University Press, 1914). 